\title{
Giant cell tumor in the thyroid area: a case report in the novel location and review of literature
}

\author{
Jia-Ying Chen ${ }^{1,2}$, Qiang Zheng ${ }^{2,3}$, Tong-Zhen Chen ${ }^{2,3}$, Qing-Hai Ji ${ }^{1,2}$, Qiang Shen ${ }^{1,2}$ \\ ${ }^{1}$ Department of Head and Neck Surgery, Fudan University Shanghai Cancer Center, Shanghai, China; ${ }^{2}$ Department of Pathology, Fudan University \\ Shanghai Cancer Center, Shanghai, China; ${ }^{3}$ Department of Oncology, Shanghai Medical College, Fudan University, Shanghai, China \\ Correspondence to: Qiang Shen; Qing-Hai Ji. Fudan University Shanghai Cancer Center, 270 Dong An Road, 200032, Shanghai, China. \\ Email: drshen_qiang@126.com; jq_hai@126.com.
}

\begin{abstract}
Giant cell tumor of soft tissue (GCT-ST) is a rare benign tumor of low malignant potential. It is thought to be the soft tissue counterpart of giant cell tumors of the bone due to its pathological resemblances. GCT-ST is most commonly found in superficial soft tissue of thigh, trunk and upper extremities. The head and neck region is rarely affected. Here for the first time, we describe a case of GCTST in the thyroid region. A 70-year-old female patient presented with a painless swelling in her left neck for the previous three weeks. The condition was initially diagnosed as thyroid goiter and left lobectomy was arranged. Intraoperative findings showed an irregular mass invading the strap muscles and trachea. Complete tumor resection was difficult, and part of the tumor was left in the thyroid bed. Histopathology of the resected specimen showed a mixture of mononuclear round to oval cells and multinucleated osteoclastlike giant cells. The giant cells were CD 68 positive. The patient received a revision surgery 3 months after the first operation to achieve complete resection. There was no recurrence in the first 3-month follow-up. However, 6 months after the revision surgery, the tumor recurred on both sides of the neck. The patient suffered from dysphagia and breathlessness. As further surgery and radiation therapy were not considered, denosumab was used as a novel agent After three months of treatment, the patient showed symptom-relief and tumor-regression. The patient continued to have tumor-regression after 1 year of the denosumab treatment. GCT-ST is a benign tumor, although in this case, it was showing features of malignancy. A review of the literature was conducted to identify previous studies on GCT-ST in the head and neck. We present this case for its rare location and novel treatment with denosumab.
\end{abstract}

Keywords: Giant cell tumor; thyroid area; case report; denosumab

Submitted Dec 02, 2020. Accepted for publication Apr 21, 2021.

doi: 10.21037 /gs-20-866

View this article at: https://dx.doi.org/10.21037/gs-20-866

\section{Introduction}

Giant cell tumor of soft tissue (GCT-ST) is a rare disease with a low malignant potential, which was first described by Salm in 1972 and followed by Guccion in the same year $(1,2)$. While GCT-ST is most commonly found in the superficial soft tissue of the thigh, trunk and upper extremities (3-5). The head and neck region is rarely affected. We present here the case of a patient with a lesion initially treated as a thyroid goiter and finally diagnosed as a GCT-ST in the thyroid bed of the neck. We present the following case in accordance with the CARE reporting checklist (available at https://dx.doi.org/10.21037/gs-20866).

\section{Case presentation}

A 70-year-old woman presented at the clinic with complaints about a painless swelling in her left neck for the previous three weeks. She denied any relevant family history or other symptoms. Neck ultrasound showed a $35 \mathrm{~mm} \times 28 \mathrm{~mm} \times 25 \mathrm{~mm}$ mixed nodule located in the 


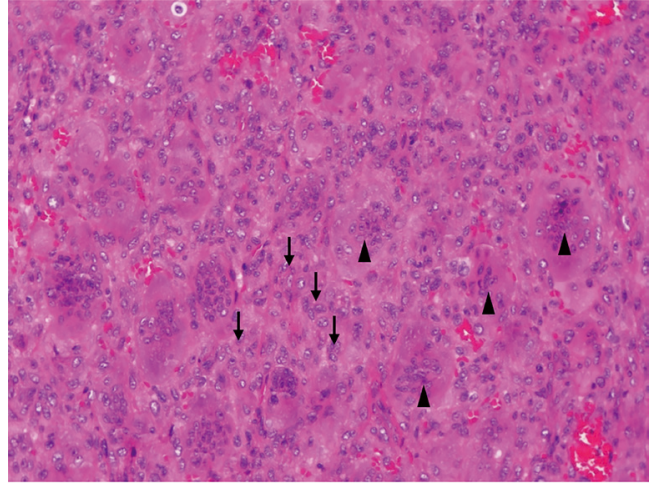

Figure 1 Tumor shows a mixture of mononuclear cells (arrows) with multinucleated osteoclast-like giant cells (arrowheads). Hematoxylin-Eosin staining, $\times 200$.

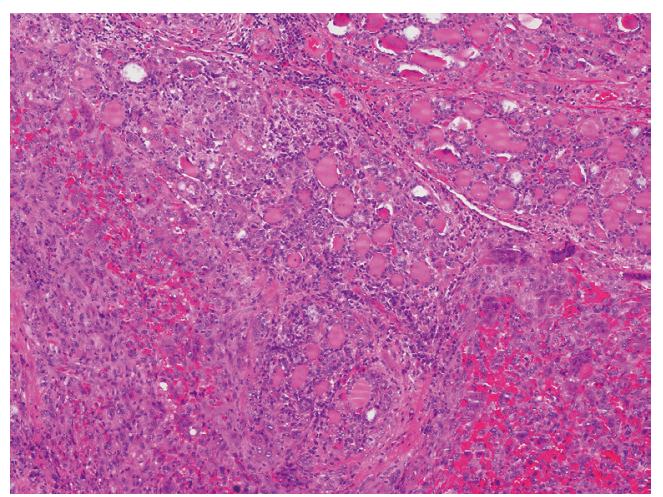

Figure 2 Tumor invasion to the parenchyma of thyroid, the residual follicles were surrounded by giant cell tumor. Hematoxylin-Eosin staining, $\times 100$.

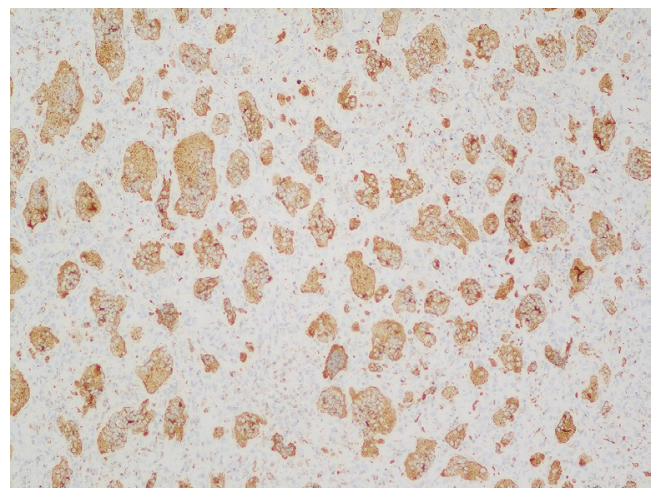

Figure 3 Immunoreactivity for CD68 showing strong cytoplasmic CD68 positivity in multinucleated giant cells. Immunohistochemistry (IHC) staining, $\times 100$. enlarged left thyroid lobe. The nodule was multiple cystic with a regular margin, eccentric solid areas and central vascularization. No lymph nodes were detected in the neck area. Thyroid function test was normal with thyroidstimulating hormone (TSH) level of $3.61 \mathrm{mIU} /$ liter. She was diagnosed with thyroid goiter and scheduled for followup after 6 months. However, 2 weeks later, she reported compression in the neck area and was referred to a general surgeon for further advice. The second ultrasound showed no difference when compared to the first, except for a slight enlargement in diameter $(42 \mathrm{~mm} \times 36 \mathrm{~mm} \times 28 \mathrm{~mm})$. The patient refused fine needle biopsy and requested surgery. No radiography or computed tomography (CT) scan was performed in the preoperative clinic. So the left lobectomy was planned on February 28, 2019. Intraoperative findings showed an irregular mass invading the strap muscles and trachea. Complete tumor resection was difficult and part of the tumor was left in the place where it adhered to the strap muscles and trachea. The left recurrent laryngeal nerve and parathyroid glands were well reserved. Grossly, the tumors displayed a rubbery cut surface. The thyroid was infiltrated by the tumor. Histologically, the tumor was multi-nodular. The characteristic findings were a mixture of mononuclear round to oval cells and multinucleated osteoclast-like giant cells (Figure 1). Mitotic activity and areas of stromal hemorrhage were observed. Necrosis or vascular invasion were not seen, but the thyroid tissues were invaded by the tumor (Figure 2). The further immunohistochemical findings revealed that the thyroid transcription factor-1 (TTF-1), the cocktail of AE1/AE3 antibodies and paired box 8 (PAX8) were positive in the thyroid area but negative in the tumor cells. On the other hand, the tumor cells had the phenotype of normal osteoclasts expressing markers of histiocytic lineage (CD68) (Figure 3). Smooth muscle actin (SMA) and P63 were both negative in the tumor area. Immunohistochemical staining for the mindbomb homolog 1 (MIB1) antibody showed a Ki67 index of $10-20 \%$. As a result of these findings, the patient was diagnosis of GCTST by two expert pathologists.

After the initial surgery, the patient was referred to our cancer center for a second opinion. Neck ultrasound showed a $35 \mathrm{~mm} \times 28 \mathrm{~mm} \times 25 \mathrm{~mm}$ solid nodule located in the left thyroid bed. The nodule was hypoechoic with irregular margins and rich in blood flow signals. (Figure 4). The postoperative cervical and thoracic CT scan (Figure 5) showed nodules in the surgical region (close to the trachea) 
and new subcutaneous nodules in the right anterior cervical region (Figure $5 A, B) .{ }^{18} \mathrm{~F}$-Fluorodeoxyglucose $\left({ }^{18} \mathrm{~F}\right.$-FDG) CT scan examination identified cervical lesions located in the left thyroid bed and lower compartment of the right neck, with standard uptake value (SUV) of 16.9. No distant metastases were found. Laryngoscopy indicated good bilateral vocal cord activity. The upper gastrointestinal air barium radiography showed no abnormalities. Fine need aspiration was arranged in both left and right lesions.

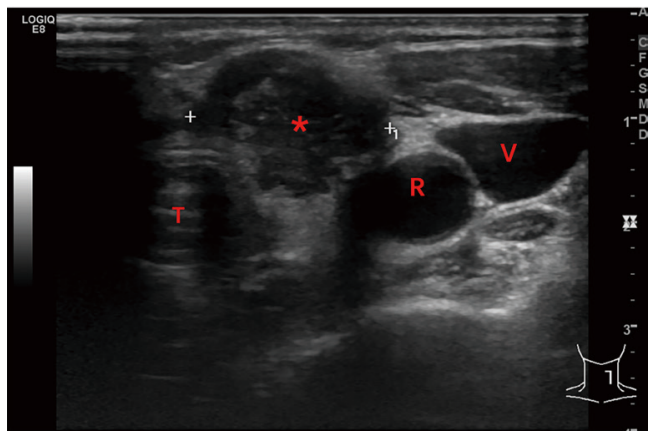

Figure 4 Ultrasound imaging on April 20. T, trachea; *, tumor lesion; $\mathrm{R}$, common carotid artery; $\mathrm{V}$, internal jugular vein.
These two lesions were suspected to be GCT-ST by cytological examination. Because the initial surgery had been incomplete (macroscopic residue, R2), the case was referred to our senior specialist surgeon (Dr. Qiang Shen) to assess the feasibility of complete definitive surgery. After considering the potential benefits and risks of the procedure, we subsequently offered the patient the revision surgery on May 9, 2019. During the operation, several nodules were identified between the right platysma and strap muscles, with the largest size of $1.5 \mathrm{~cm}$. A nodule with a maximum diameter of $3 \mathrm{~cm}$ was identified in the left thyroid bed. The tumor had invaded the recurrent laryngeal nerve and part of the trachea, which was hard to separate. Thus, all tumors include recurrent laryngeal nerve, partial tracheal rings and right thyroid lobe were removed (R0). Postoperative pathology confirmed GCT-ST (Figure 6). In the postoperative setting, the patient complained of hoarseness, without any symptoms of dyspnea or hypocalcemia. She was discharged from our ward 2 weeks after surgery and advised to have radiotherapy as an adjuvant treatment. The patient refused to have radiotherapy considering the potential radiation exposure and her elderly age. She was then asked to attend for routine follow-up every 3 months.
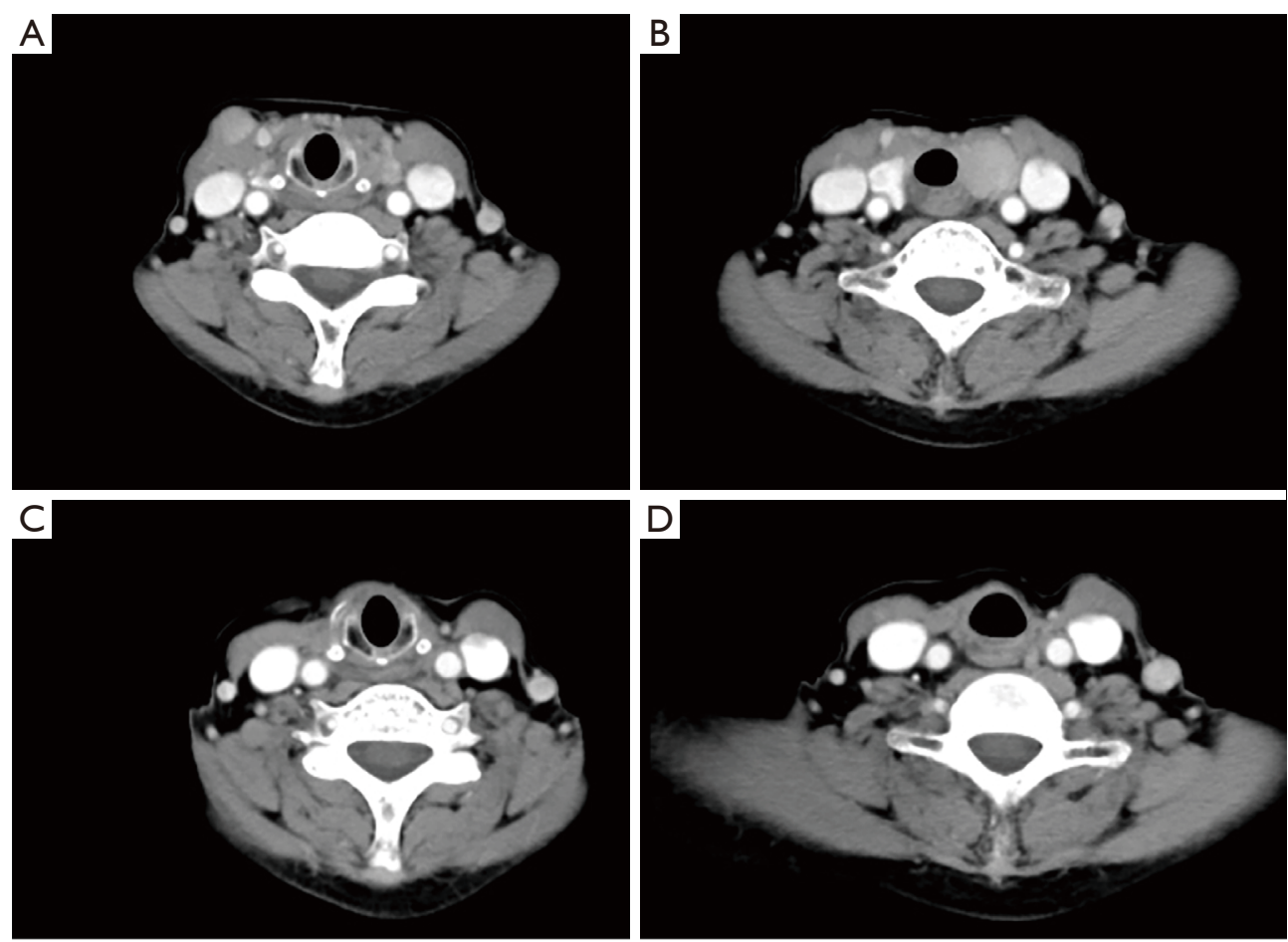

Figure 5 Computed Tomography (CT) scan before and after the revision surgery. (A,B) CT scan before the revision surgery (08 May 2019); (C,D) CT scan after the revision surgery (19 August 2019). 


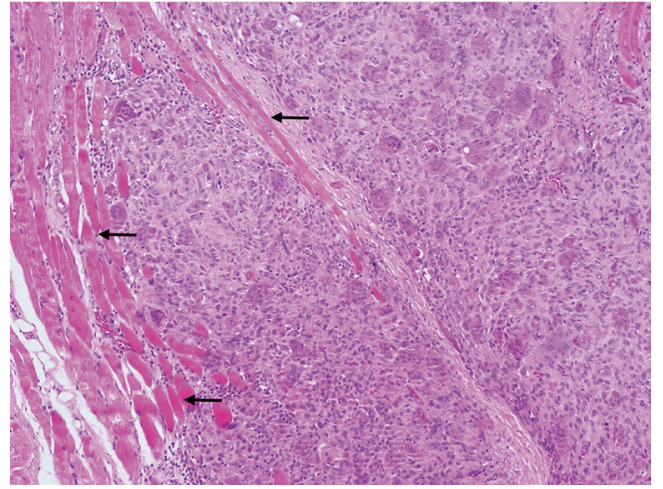

Figure 6 Tumor invasion to the striated muscles in the recurrent lesions (arrows), the morphology was identical with primary lesion. Hematoxylin-Eosin staining, $\times 200$.
On August 19, 2019, the patient attended the followup clinic and her cervical CT showed no evidence of recurrence (Figure 5C,D). Two months later in October, she felt a swelling in the left neck. The mass on the right neck developed rapidly during the next 5 weeks. When the patient attended the clinic on November 18, 2019, her neck mass was evident clinically, and the patient was suffering from dysphagia and breathlessness. The cervical CT revealed multiple nodes in the right compartment of the neck with a maximum diameter of $5.7 \mathrm{~cm}$ (Figure $7 A, B$ ). The nodules had compressed the trachea and esophagus. No distant metastases were found. Esophagoscopy revealed external esophageal pressure. The patient was not in a good condition and could only eat soft food. After a
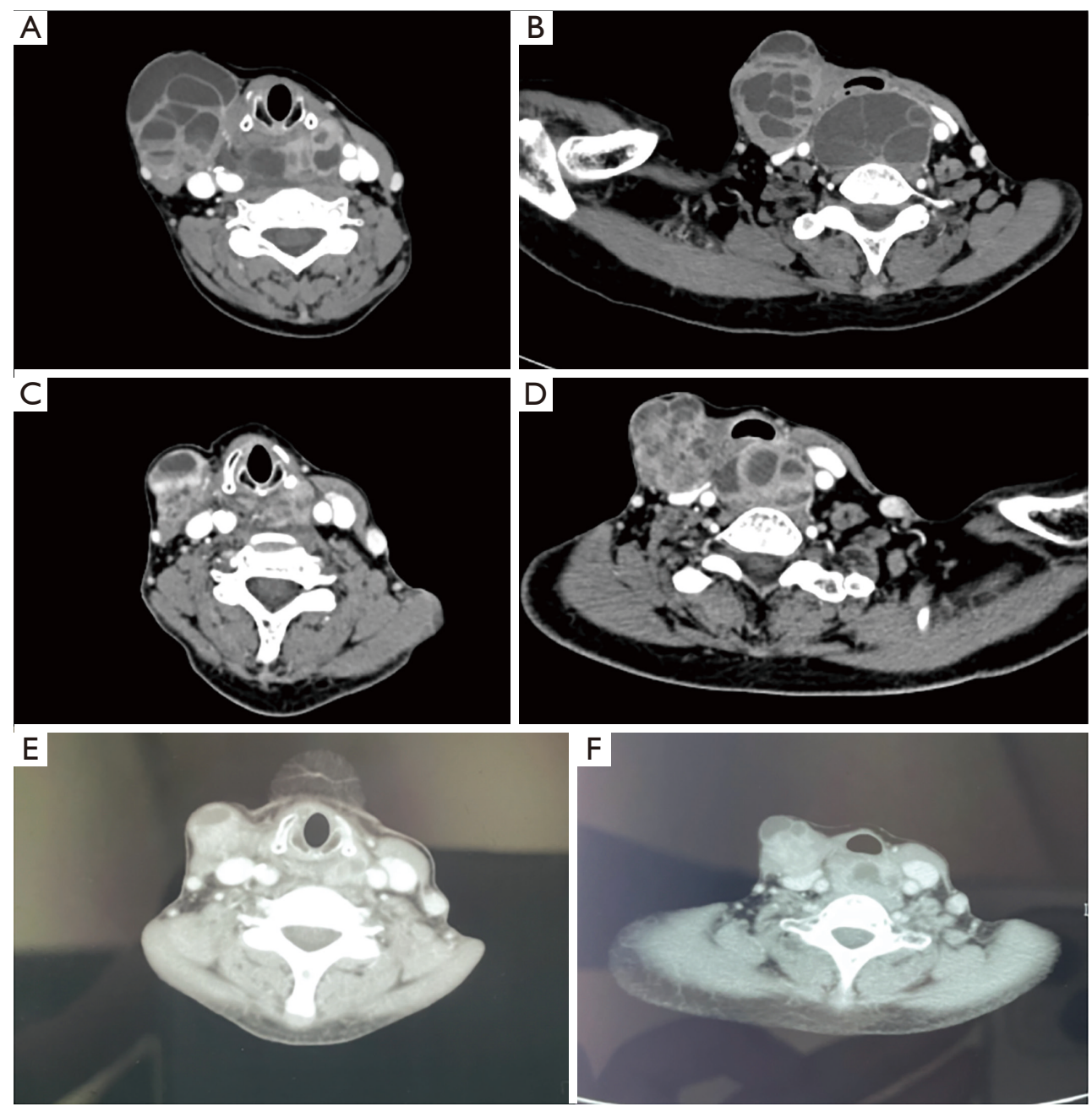

Figure 7 Computed Tomogram (CT) scan before and after treating with denosumab. (A,B) CT scan before treating with denosumab ( 18 November 2019); (C,D) CT scan after 3 months of denosumab treatment (02 March 2020); (E,F) CT scan after 1 year of denosumab treatment (19 December 2020). 
comprehensive and systematic evaluation, it was decided that the patient was not suitable for more surgery or radiotherapy. And as a rare disease, no clinical trials were available. Recently, in May 2019, the RANKL inhibitor (denosumab) was approved by the CFDA for the treatment of GCT in the bone. We subsequently offered the patient treatment with denosumab as a novel agent. The patient received subcutaneous injections of denosumab $120 \mathrm{mg}$ every 28 days, with an additional loading dose on days 8 and 15 of month 1 from November 30, 2019. Three months after initiation of denosumab, the patient demonstrated symptom-relief. No other side effects were reported. CT scan showed a significant modification of the lesion. The anteroposterior diameter was significantly decreased from 5.7 to $4.4 \mathrm{~cm}$ (Figure $7 C, D)$. So the patient continued to have denosumab as a maintenance treatment. After 1 year of denosumab injection in late December 2020, the patient had a further CT scan at her local hospital. The tumor lesion was stable. The anteroposterior diameter was $3.7 \mathrm{~cm}$ after 1 year of denosumab treatment (Figure $7 E, F$ ).

All procedures performed in studies involving human participants were in accordance with the ethical standards of the institutional and/or national research committee(s) and with the Helsinki Declaration (as revised in 2013). Written informed consent was obtained from the patient.

\section{Discussion}

GCT-ST is described as a rare kind of soft tumor characterized by the presence of spindles or polygonal mononuclear cells and multinucleated osteoclast-like giant cells (6). GCT-ST has a benign clinical course in most patients, with exceedingly low recurrence and metastatic rates. Oliveira et al. reviewed 22 cases in the Mayo Clinic files that only one patient had local recurrence and lung metastases who died of the tumor (4). GCT-ST patients arising from the head and neck are an extremely rare entity. We conducted a literature review by searching PubMed (https://www.ncbi.nlm.nih.gov) with the key words "giant cell tumor of soft tissue". Then we selected the patients whose lesions originated in the head and neck. In total, only 12 cases were reported between 1910 and 2019 (4,5,7-16). The clinical characteristics and outcomes of these 12 cases were listed in Table 1.

GCT-ST in the head and neck does not show age or sex predilection. It is a rare neoplasm involving both superficial and deep soft tissues. In the literature review, seven of the 12 patients had tumors that were located superficially
$(4,5,7,9,12,14,15)$. In most patients, the chief complaint is an asymptomatic, multinodular, well-circumscribed mass with or without dermal involvement covered by normal skin or a fleshy red-brown surface when superficially located. In our case, the tumor was located deep in the left thyroid area (between the trachea and carotid artery), which made early detection difficult. Ultrasonography can help establish the diagnosis by determining the texture of the cervical mass, but often not the exact anatomical origin. It is difficult and even impossible to achieve a correct diagnosis by sonography alone. The most common image in CT or magnetic resonance imaging (MRI) is a solid, heterogeneous, frequently hemorrhagic mass (4). CT and MRI may also be helpful in the operative setting for locating the exact anatomical origin. In our patient, the tumor location and results of ultrasound initially led to the diagnosis of thyroid goiter. Unfortunately, no CT or MRI was applied before the primary surgery, which led to the misdiagnosis.

Currently, GCT-ST remains a confusing and difficult subtype of the group of so-called fibrohistiocytic tumors of intermediate (borderline) malignancy (17). The pathological description includes osteoclastic giant cells and a mononuclear component. The giant cells are evenly distributed uniformly throughout the tumors; the mononuclear component may be composed of round, oval or spindled cells. Mitotic activity could be observed in more than half of the cases while cystic changes are present in approximately $30 \%$ of tumors $(3,4)$ Foci of necrosis are very rare and cytological atypia is not seen in this type of tumor (18). The peculiar bone formation observed in some cases of GCT-ST, in the form of a bony shell around the tumor. GCT-ST usually show an immunohistochemical staining profile similar to GCT of bone, displaying immunoreactivity for CD68 mainly in the osteoclast-like giant cells and focally in the mononuclear stromal cells. Histopathologically, GCT-ST should be separated from other tumors which can also show prominent giant cell component (19). Malignant GCT-ST is extremely rare, characterized by nuclear atypia, pleomorphism and atypical abundant mitoses (20). In this case, GCT arising in the thyroid area should be differentiated with an osteoclastic variant of anaplastic thyroid carcinoma (ATC) which is defined as a highly malignant tumor wholly or partially composed of undifferentiated cells that retain features indicative of an epithelial origin, on immunohistochemical or ultrastructural grounds (21). However, GCT-ST is composed of bland mononuclear tumor cells and 
Table 1 The clinical characteristics and outcome of 12 GCT-ST cases located in head and neck

\begin{tabular}{|c|c|c|c|c|c|c|c|c|}
\hline Year & Study & Sex & $\begin{array}{l}\text { Age } \\
\text { (year) }\end{array}$ & Location & $\begin{array}{l}\text { Tumor } \\
\text { size }(\mathrm{cm})\end{array}$ & Level & Treatment & Follow-up \& outcome \\
\hline 1981 & Angervall (5) & M & 75 & Neck, L & 3 & Superficial & Local excision & $\begin{array}{c}\text { Died after } 1.5 \text { years with multiple } \\
\text { subcutaneous, tumors, and lung } \\
\text { metastases }\end{array}$ \\
\hline 2000 & Oliveira (4) & M & 9 & Neck, L & N/A & Superficial & N/A & N/A \\
\hline 2007 & Tuluc (8) & $\mathrm{F}$ & 32 & Nasal cavity & 0.7 & Deep & Local excision & 1 year, NED \\
\hline 2006 & Grabellus (9) & M & 73 & $\begin{array}{l}\text { Temporal } \\
\text { forehead, L }\end{array}$ & 1 & Superficial & Local excision & $\begin{array}{l}\text { relapses after } 6 \text { and } 11 \text { months in } \\
\text { the parotid region, excision }\end{array}$ \\
\hline 2010 & Pepper (10) & $\mathrm{F}$ & 59 & Parotid, L & 2 & Deep & $\begin{array}{l}\text { Parotidectomy } \\
\text { + postoperative } \\
\text { radiotherapy }\end{array}$ & N/A \\
\hline 2014 & Callı (12) & $\mathrm{F}$ & 53 & Neck, L & 3 & Superficial & $\begin{array}{l}\text { Local excision+ } \\
\text { postoperative } \\
\text { radiotherapy }\end{array}$ & 2 years, NED \\
\hline 2013 & Mishra (13) & M & 22 & Temporal, L & $\mathrm{N} / \mathrm{A}$ & Deep & Subtotal resection & 6 months, NED \\
\hline 2014 & Righi (14) & $\mathrm{F}$ & 36 & Lip & 1.5 & Superficial & Local excision & $\begin{array}{l}\text { Relapses on Glutus after } \\
6 \text { months, excison }\end{array}$ \\
\hline 2015 & $\begin{array}{l}\text { Bandyopadhyay } \\
\text { (15) }\end{array}$ & M & 35 & $\begin{array}{c}\text { Submandibular, } \\
\text { R }\end{array}$ & 4.5 & Superficial & Local excision & 2 years, NED \\
\hline 2017 & Hafiz (16) & $\mathrm{F}$ & 28 & Ear, $\mathrm{R}$ & 1.7 & Deep & Local excision & 1 year, NED \\
\hline
\end{tabular}

GCT-ST, giant cell tumor of soft tissue; R, right; L, Left; N/A, not available; NED, no evidence of disease.

osteoclastic giant cells. Unlike GCT-ST, the osteoclastrich anaplastic carcinoma is highly aggressive. Tumor necrosis, cytologic pleomorphism and mitotic activity are usually prominent. Though tumor-infiltrating macrophages and multinucleated giant cells are frequent, the tumor cells are often highly atypical spindle or sarcomatoid cells. Vascular invasion is often present. Immunohistochemically, thyroid-lineage markers such as PAX8 are usually retained in ATC cells, whereas GCT is consistently negative for PAX8. Cytokeratin (CK) is usually negative in GCT, and while expression of CK supports the epithelial nature of ATC, negative staining of CK could not totally exclude the diagnosis.

GCT-ST is typically treated by conservative surgical resection but excision margins are unclear. Incomplete surgical excision due to an infiltrative growth pattern that can involve deep delicate anatomical structures is usually followed by local recurrence (22). Given the benign biology, postoperative radiotherapy for GCT-
ST remains controversial; however, radiation may be considered when the resection is incomplete or with negative surgical margins. Information regarding the treatment of GCT-ST in the head and neck was available in 11 patients. All patients were treated surgically, with two of them administering postoperative radiotherapy $(10,12)$. Follow-up and clinical outcomes were recorded in 9 of 12 patients. One elder man died after 1.5 years with multiple subcutaneous tumors and lung metastases (5). Two had relapses several months later and received further surgeries again, remaining alive at the time of the last follow-up $(9,14)$. However, the lack of large studies and long-time followup makes it difficult to conclude the biologic behavior and outcome of the patients with these tumors. In our case, the patient presented with more aggressive clinical courses with rapid local recurrence and lost the opportunity of complete revision surgery.

Denosumab is a human monoclonal antibody that inhibits osteoclast mediated bone destruction and provides 
rapid and sustained suppression of bone turnover. It has been thought to inhibit the activity of osteoclast-like giant cells via RANK- RANKL pathway in GCT and approved by CFDA recently in patients with GCT of bones (23). Histologically, the treatment depletes the osteoclastic giant cells. In case that GCT-ST and giant cell tumor of bone show a similar line of differentiation and run identical clinicopathologic courses, denosumab was administered to our patient. After three months of treatment, the patient demonstrated symptom-relief as well as tumor-regression.

The unusual presentation and location made this case very interesting. To our knowledge, this is the first report of GCT-ST located in the thyroid area and treated with denosumab. Actually, the rare location deep in the thyroid region caused the initial misdiagnosis. This case seemed to show a more aggressive clinical course, which was relapsed quickly after the surgery. And pathologically, it showed some malignant features as invasion to the thyroid tissues and muscles. Even without distant metastasis, the local recurrence in the neck caused dysphagia and breathlessness, which may cause sudden death. Our innovative use of denosumab relieved the patient's symptoms and created tumor shrinkage, making this treatment very worthy of further exploration.

\section{Acknowledgments}

Funding: None.

\section{Footnote}

Reporting Checklist: The authors have completed the CARE reporting checklist. Available at https://dx.doi. org/10.21037/gs-20-866

Peer Review File: Available at https://dx.doi.org/10.21037/ gs-20-866

Conflicts of Interest: All authors have completed the ICMJE uniform disclosure form (available at https://dx.doi. org/10.21037/gs-20-866). The authors have no conflicts of interest to declare.

Ethical Statement: The authors are accountable for all aspects of the work in ensuring that questions related to the accuracy or integrity of any part of the work are appropriately investigated and resolved. All procedures performed in studies involving human participants were in accordance with the ethical standards of the institutional and/or national research committee(s) and with the Helsinki Declaration (as revised in 2013). Written informed consent was obtained from the patient.

Open Access Statement: This is an Open Access article distributed in accordance with the Creative Commons Attribution-NonCommercial-NoDerivs 4.0 International License (CC BY-NC-ND 4.0), which permits the noncommercial replication and distribution of the article with the strict proviso that no changes or edits are made and the original work is properly cited (including links to both the formal publication through the relevant DOI and the license). See: https://creativecommons.org/licenses/by-nc-nd/4.0/.

\section{References}

1. Salm R, Sissons HA. Giant-cell tumours of soft tissues. J Pathol 1972;107:27-39.

2. Guccion JG, Enzinger FM. Malignant giant cell tumor of soft parts.An analysis of 32 cases. Cancer 1972;29:1518-29.

3. O'Connell JX, Wehrli BM, Nielsen GP, et al. Giant cell tumors of soft tissue: a clinicopathologic study of 18 benign and malignant tumors. Am J Surg Pathol 2000;24:386-95.

4. Oliveira AM, Dei Tos AP, Fletcher CD, et al. Primary giant cell tumor of soft tissues: A study of 22 cases. Am J Surg Pathol 2000;24:248-56.

5. Angervall L, Hagmar B, Kindblom LG, et al. Malignant giant cell tumor of soft tissues: A clinicopathologic, cytologic, ultrastructural, angiographic, and microangiographic study. Cancer 1981;47:736-47.

6. World Health Organization Classification of Tumours. Pathology and geneties of tumours of soft tissue and bone. Lyon: IARC Press, 2002:118-9.

7. Hoang MP, Rogers BB, Albores-Saavedra J. Giant cell tumor of the skin: A morphologic and immunohistochemical study of five cases. Ann Diagn Pathol 2002;6:288-93.

8. Tuluc M, Zhang X, Inniss S. Giant cell tumor of the nasal cavity: Case report. Eur Arch Otorhinolaryngol 2007;264:205.

9. Grabellus F, von Winterfeld F, Sheu S, et al. Unusual aggressive course of a giant cell tumor of soft tissue during immunosuppressive therapy. Virchows Arch 2006;448:847-51.

10. Pepper T, Falla L, Brennan P. Soft tissue giant cell tumour of low malignant potential arising in the masseter-a rare 
entity in the head and neck. Br J Oral Maxillofac Surg 2010;48:149-51.

11. Trabelsi A, Hammedi F, Slama A, et al. Giant cell tumor of soft tissue of neck: A case report. N Am J Med Sci 2009;1:319.

12. Callı AO, Tunakan M, Katilmiş H, et al. Soft tissue giant cell tumor of low malignant potential of the neck: a case report and review of the literature. Turk Patoloji Derg 2014;30:73-7.

13. Mishra SS, Senapati SB, Dhir MK, et al. Intracranial giant cell tumor of soft tissue: Mimicking a glioma. Neurol India 2013;61:192-3.

14. Righi S, Boffano P, Patetta R, et al. Soft tissue giant cell tumor of low malignant potential with 3 localizations: Report of a case. Oral Surg Oral Med Oral Pathol Oral Radiol 2014;118:e135-8.

15. Bandyopadhyay A, Khandakar B, Medda S, et al. Giant cell tumour of soft tissue in neck: An uncommon tumour in an uncommon location. J Clin Diagn Res 2015;9:ED19.

16. Hafiz S, Shaheen M, Awadh N, Esheba G. Giant cell tumor of soft tissue: A case report for the first time in ear. Hum Pathol 2017;10:12-4.

17. Folpe AL, Morris RJ, Weiss SW. Soft tissue giant cell

Cite this article as: Chen JY, Zheng Q, Chen TZ, Ji QH, Shen Q. Giant cell tumor in the thyroid area: a case report in the novel location and review of literature. Gland Surg 2021;10(6):2054-2061. doi: 10.21037/gs-20-866 tumor of low malignant potential: a proposal for the reclassification of malignant giant cell tumor of soft parts. Mod Pathol 1999;12:894-902.

18. Fletcher CDM, Bridge JA, Hogendoorn PCW, et al. WHO Classification of Tumours of Soft Tissue and Bone, vol. 5. 4th ed. Lyon, France: IARC Press, 2013.

19. Lee JC, Huang HY.Soft Tissue Special Issue: Giant CellRich Lesions of the Head and Neck Region.Head Neck Pathol 2020;14:97-108.

20. Dodd LG, Major N, Brigman B. Malignant giant cell tumor of soft parts. Skeletal Radiol 2004;33:295-9.

21. Deeken-Draisey A, Yang GY, Gao J. Anaplastic thyroid carcinoma: an epidemiologic, histologic, immunohistochemical, and molecular single-institution study. Human pathology 2018;82:140-8.

22. Holst VA, Elenitsas R. Primary giant cell tumor of soft tissue. J Cutan Pathol 2001;28:492-5.

23. Thomas D, Henshaw R, Skubitz K, et al. Denosumab in patients with giant-cell tumour of bone: an open-label, phase 2 study. Lancet Oncol 2010;11:275-80.

(English Language Editor: Dianne Fitzgerald and Jeremy Chapnick) 